\title{
The Index of Learning Styles as Predictors of Cave Hill Undergraduate Chemistry Students' Achievement in Inorganic Chemistry
}

\author{
Leah D Garner-O'Neale, PhD*
}

\author{
Faith Brooks \\ Department of Biological \& Chemical Sciences \\ Faculty of Science \& Technology \\ The University of the West Indies \\ Cave Hill Campus, Barbados \\ Email: leah.garner-oneale@cavehill.uwi.edu
}

Doi:10.5901/ajis.2013.v2n2p299

\begin{abstract}
This study was conducted to determine the learning styles of the undergraduate chemistry students at the University of the West Indies (the UWI) Cave Hill Campus and to see if they made any contribution to the academic achievement scores of the chemistry students in two aspects of inorganic chemistry: group theory and non-group theory chemistry. An adapted index of learning styles questionnaire was used to determine the learning styles of the undergraduate chemistry students. The reliability of the questionnaire was determined using the Cronbach's alpha. A total of 58 students participated in the study and the data collected was analyzed by t-test, ANOVA and linear regression via the Predictive Analysis Software (PASW) at a confidence level of 0.05. The study showed that the majority of the chemistry students were active, sensate, visual and sequential learners. The contribution of the learning styles as predictors of a chemistry student's academic achievement was negligible and not statistically significant in either group theory or non-group theory chemistry. However, the active/reflective learning style category was the highest contributor towards non-group theory chemistry whereas the sequential/global learning style category was the highest contributor towards academic achievement in group theory chemistry.
\end{abstract}

Keywords: learning style, academic achievement, chemistry, inorganic chemistry, group theory

\section{Background}

Educational leaders agree that learning styles have an important function in education, with reference to teaching styles (Montgomery \& Groat, 1998). Felder stated that learners with a strong preference for a specific learning style may have difficulties in learning if the teaching style does not match with their learning style (Richard M Felder \& Spurlin, 2005). This statement was deep-rooted by a study that showed that students who attended an online course that matched with their preferred learning style achieved significantly better results than those who were given a course that did not match their learning style (Bajraktarevic, Hall, \& Fullick, 2003).

A learning style is the way in which a student can assimilate the information available to them during the process of learning (Dunn \& Dunn, 1993). Learning styles can be defined as the, "composite of characteristic cognitive, affective, and physiological factors that serve as relatively stable indicators of how a learner perceives, interacts with, and responds to the learning environment" (Keefe, 1979). Cognitive factors or "cognitive styles," are intrinsic information-processing patterns that represent a person's typical mode of perceiving, thinking, remembering, and problem solving (Griggs, 1991). Learning styles are those "educational conditions under which a student is most likely to learn" (Stewart \& Felicetti, 1992). Most simply conceived, learning style is the typical way an individual likes to go about learning. Although there are characteristics of learning style that are quite stable in an individual across different learning tasks and contexts, there can still be variation in the same learner (Smith \& Dalton, 2005). The ideal way in which an individual, in this case a student, approaches a learning situation has been characterized by a variety of theoretical models (Cassidy, 2004). The models are grouped according to the Curry "Onion" Model (Bonham \& Boylan, 1993).

The Curry's "Onion" Model is a standard method of classifying learning style models (Bonham \& Boylan, 1993; Coffield, Moseley, Hall \& Ecclestone, 2004; Center for Instruction, 2012). It groups these learning styles into; instructional 
preferences, social interaction preferences, information processing and personality levels (Coffield, et al., 2004; Center for Instruction, 2012).

Instructional preferences focuses on the most observable traits, for example; environmental, emotional and sociological preferences (Gordon \& Bull, 2004). The Dunn and Dunn learning styles model comes under this category. It was developed by Rita Dunn and Kenneth Dunn in the 1970's and is divided into five strands: environmental, emotional, sociological, physiological and psychological (Dunn \& Dunn, 1993; Dunn \& Griggs, 1998).

Social interaction preferences focus on the ability of learners to interact with their peers in the learning process. An example of this type of model would be the Reichmann and Grasha's type model (Griggs, 1991; Sidek, Noor \& Jusoff, 2009). The Grasha-Reichmann learning styles scales were developed by Anthony Grasha and Cheryl Reichmann in 1974 to examine the class room participation styles in college students ( SUNY Cortland, n.d; Heineman, 1995; Sidek et al., 2009). This learning style scale places more emphasis on student attitudes to learning, classroom activities, teachers and peers, and stresses an increase in ability to problem-solve, communicate with others and organise materials (Ritchie, 2006).

Personality levels focus on a person's personality can influence their ability to acquire and integrate information. The Myers-Briggs Type Indicator (MBTI) is based on personality levels (Gordon \& Bull, 2004; Cuthbert, 2005). It was developed by Isabel Myers and Katherine Briggs during the 1940's based on Carl Jung's theory of psychological types (Pittenger, 1993). There are four dimensions of the model: Extroversion vs. Introversion; Sensing vs. Intuition, Thinking vs. Feeling; Judging vs. Perception (Cuthbert, 2005; Pittenger, 1993).

The information processing models deals, with how a person obtains, sorts, stores and utilizes information (Gordon \& Bull, 2004; Hickcox, 1995). The Felder-Silverman learning style model (FSLSM) developed by Richard Felder and Linda Silverman in 1988 is one such model (Cassidy, 2004). It chiefly focuses on the aspects of learning styles in science students, more specifically engineering students (Kanninen, 2008). This learning style model is often used in technology enhanced learning but is designed for traditional learning (Felder \& Silverman, 1988). While most other learning styles classify their learners in a few groups, the FSLSM describes the learning style of a student in four dimensions (Felder \& Henriques, 1995). Another distinguishing factor is that with other learning style models, the learners are classed into set groups, the FSLSM characterises a learner by a specific preference for each of these dimensions.

The first dimension distinguishes between the active and the reflective way of processing information (Felder \& Brent, 2005). Active learners accomplish more by, 'actively working with the learning material by applying the material and by trying things out' (Graf, Viola, Leo, \& Kinshuk, 2007). Active learners are more socially oriented and prefer to learn in groups where they can discuss the learned material. Reflective learners on the other hand, prefer to sit, think and reflect on the material they receive. They prefer to work alone or with one good friend (Montgomery \& Groat, 1998; Graf, et al., 2007).

The second dimension differentiates between sensing and intuitive learning. Sensing learners prefer to learn concrete learning material and facts. They are very careful with details, solve problems with standard approaches and tend to be more practical comparatively (Felder \& Henriques, 1995; Graf, et al., 2007). They like to relate the information learned to the real world. Intuitive learners lean towards learning abstract material like theories and their underlying meanings. They are more able to discover possibilities and relationships, usually more innovative and creative and are not very careful with details (Graf, Viola, \& Kinshuk, 2006; Graf, et al., 2007).

The third dimension covers the visual versus the verbal learners. Visual learners recall information best if it is presented to them visually whether it is pictures, diagrams or flow charts. Verbal learners remember best when the information is offered in, 'textual representations, regardless of whether they are written or spoken' (Graf, et al., 2006).

In the fourth dimension, learners are categorized according to their understanding. Sequential learners learn in small incremental steps and tend to follow a logical, stepwise path to solve problems. They are interested in details and usually understand all parts to see the whole picture. Global learners absorb learning material almost randomly (Graf, et al., 2006). They tend not see individual connections but when they gather enough information, they, 'suddenly see the big picture'(Graf, et al., 2007).

The Index of Learning Styles (ILS), based on the FSLSM was developed by Felder and Solomon and has been used with engineering students (Felder, 1995). Literature shows that engineering students tend to be visual, sensing, active sequential learners but the Aalto University engineering students although they also were predominantly visual, sensing, learners, showed a balance with the active/reflective and sequential/ global learning styles (Zywno \& Waalen, 2002; Havola, Silferberg, \& Joutsenlahti, 2011). Communication science students were also studied at the Tampere University using this learning style scale and they were found to be mainly intuitive, global learners (Vainionpää, 2006). 
In this study, the index of learning styles (Felder, 1996), is used to determine the learning styles in a select group of chemistry students. This learning style inventory was used because Felder advocates a multi-style approach to science and engineering education and he incorporated active, collaborative and student-centred learning (Felder \& Silverman, 1988; Felder, Felder, \& Dietz, 1998). The Index of learning styles was also used because it was easy to see the styles expected in chemistry students and it was easy to understand and work with.

Graham, Garton and Gowdy (2001) noted that a student's learning style can be an important variable in his or her academic achievement. It is therefore important for all educators to know how their students learn in order for them to know the best way to teach and assess them since learning styles can be a predictor of academic achievement (Vawda, 2005). It is also important for learners to understand the factors, in this instance learning styles, that may impact their academic performance since such an understanding can increase their motivation, help them to make positive attitudes towards learning and decrease their achievement related anxiety (Matthews, 1991). The literature shows that learning styles do influence a student's academic achievement (Matthews, 1991; Kagan \& Kogan, 1970; Chapelle, 1995). Studies show that low achievers have different learning styles when compared to high achievers. It also states that they vary also among themselves meaning, high achievers have different learning styles to other high achievers etc. (Abidin, Rezaee, Abdullah, \& Singh, 2011). A study by Kagan and Kogan (1970) showed that impulsive students compared to thoughtful students, show poor academic achievement and another showed that students with the field-independent learning style achieve more than students with the field-dependent learning style. Although it has been found that learning styles of a student do influence their academic achievement, most of these findings were all based on research conducted outside the Caribbean and the results may vary as the teaching styles might vary in the Caribbean since cultural environment is also important (Damavandi, Mahyuddin, Elias, Daud, \& Shabani, 2011). In fact, a recent study done at the University of the West Indies (UWI) Cave Hill campus with chemistry students involved in group theory chemistry courses showed that learning styles, determined using the Paragon Learning Style Inventory (PLSI) which is based on personality traits, did not significantly contribute to their academic achievement (Garner-O'Neale \& Harrison, 2013).

\section{Purpose of Study and Research Questions}

In this study, researchers sought to determine if learning styles determined by the ILS, which is based on how students process information, influence the academic achievement of the students in group theory and non group theory chemistry courses at the UWI Cave Hill Campus. The questions used to guide this research are as follows:

1. What are the prevailing learning styles among undergraduate chemistry students in the department of Biological and Chemical Sciences based on the index of learning styles?

2. Is there any significant difference in these learning styles based on the students' a) level of study or b) age?

3. Is there any significant difference in the academic achievement of undergraduate chemistry students in group theory and non group theory chemistry based on their categories of learning styles?

4. To what extent do the learning styles predict the level of academic achievement of the undergraduate chemistry students in both group theory and non group theory chemistry courses?

5. What is the relative contribution of each learning style on the level of academic achievement of the undergraduate chemistry students in both group theory and non group theory chemistry courses?

\section{Methodology}

\subsection{Research Design and Instrumentation}

The design utilized in this study was the descriptive research design. The questionnaire used consisted of two parts; demographics and the index of learning styles questionnaire. The demographics included an identifier for the lecturer to access test scores, sex, age, major or minor or both, and level of study. The Index of Learning Styles Questionnaire used was adapted from that developed by Richard Felder and Barbara Solomon (Felder \& Soloman, 2000). The questionnaire was divided up into four sections; measuring the Active/Reflective learning styles; the Sensate/Intuitive learning styles; the Visual/Verbal learning styles; and the Sequential/Global learning styles. The participants were asked to state their preference by choosing either (a) or (b) after reading the statements carefully. 


\subsection{Pilot Study}

The ILS has been used sucessfully in other studies and has been proven both reliable and valid but since this was done for a different cultural setting it was necessary to conduct a pilot to test the reliability of the instrument used. All the second year inorganic student participated in the pilot and the data was analysed using Predictive Analysis Software (PASW) particularly the Cronbach alpha reliability test. The Cronbach alpha reliability test was used because it was easier to use compared to other estimates and it required only one test administration. A acceptable range of alpha values is usually between 0.7 to 0.9 but lower values have previously been used in literature (Nunnally, Bernstein, \& Berge, 1967; Tavakol \& Dennick, 2011).

The reliability of the index of learning styles questionnaire was determined to be 0.50 . The questionnaire was then measured via the categories within the questionnaire; the Active/Reflective category had a Cronbach alpha reliability coefficient of 0.74 after removing two questions; the Sensate/Intuitive category had a coefficient of 0.60 after removing four questions; the Visual/Verbal category 0.71 after removing two questions; and the Sequential/Global category 0.45 after removing two questions. For the Sequential/Global category, further removal of questions did not improve the coefficient value but the category was used because it was deemed necessary for the study being conducted.

\subsection{Actual Study}

\subsubsection{Sample}

A total of 58 first and third year undergraduate chemistry students from the UWI, Cave Hill campus voluntarily participated in the study. Of them 49 were females and 9 were males, 37 declared chemistry as either their major or minor and 21 were taking chemistry as a prerequisite or an elective.

\subsubsection{Data Analysis}

PASW was used to analyze all the collected data. For research question 1, to determine the prevailing learning styles, frequencies and percentages were used. ANOVA and t-test were used to determine if there were any significant difference in the learning styles based on the age and level of study respectively. For research question 3 to determine if there was any significant difference in the academic achievement of the participants based on their categories of learning styles and their combined learning styles t-test and ANOVA were used respectively. Linear regression was used to determine the extent that the participants' learning styles predict their level of academic achievement and the relative contribution each learning style had on the level of academic achievement they achieved (research questions 4 and 5). A confidence level of 0.05 was used throughout the study therefore a $P$ value above 0.05 suggests that there is no significant difference between the learning style categories and the level of the chemistry students. A mean value lower than 1.5 suggests that the students are more active, sensate, visual or sequential depending on the learning style category being studied. A mean value above 1.5 suggests that the students in that level are more reflective, intuitive, verbal or global depending on the learning style category being studied.

\section{Results and Discussion}

\subsection{Distribution of Age and Level of study}

\subsubsection{Age}

Table 1: Distribution of age among the undergraduate chemistry students at the University of the West Indies, Cave Hill Campus.

\begin{tabular}{|c|c|c|}
\hline Age & Frequency & Percentage \\
\hline $\mathbf{1 6 - 1 8}$ & 15 & 25.9 \\
\hline $\mathbf{1 9 - 2 1}$ & 31 & 53.4 \\
\hline $\mathbf{2 2 - 2 4}$ & 7 & 12.1 \\
\hline $\mathbf{2 5 +}$ & 5 & 8.6 \\
\hline Total & 58 & 100 \\
\hline
\end{tabular}


Table 2 shows that $25.9 \%$ of the students are between the ages of 16 and $18 ; 53.4 \%$ of the students are between the ages of 19 and $21 ; 12.1 \%$ of the students are between the ages of 22 and 24 and; $8.6 \%$ of the students are 25 years and above.

\subsubsection{Level}

Table 2: Distribution of the levels among the undergraduate chemistry students at the University of the West Indies, Cave Hill Campus.

\begin{tabular}{|c|c|c|}
\hline Level & Frequency & Percentage \\
\hline First year & 36 & 62.1 \\
\hline Third year & 22 & 37.9 \\
\hline Total & 58 & 100 \\
\hline
\end{tabular}

Table 2 shows that $62.1 \%$ of the students are in the first year of their degree and $37.9 \%$ of the students are in the third year of their degree.

\subsection{Distribution of Learning Styles (Research Question 1)}

Table 3: Distribution of the styles among the undergraduate chemistry students at the UWI, Cave Hill Campus.

\begin{tabular}{|l|c|c|}
\hline & Frequency & Percentage \\
\hline Active & 36 & 62.1 \\
\hline Reflective & 22 & 37.9 \\
\hline Sensate & 40 & 69.0 \\
\hline Intuitive & 18 & 31.0 \\
\hline Visual & 42 & 72.4 \\
\hline Verbal & 16 & 27.6 \\
\hline Sequential & 42 & 72.4 \\
\hline Global & 16 & 27.6 \\
\hline
\end{tabular}

In the active/reflective category, the majority of the participants were active rather than reflective; in the sensate/intuitive category the majority of the participants were sensate rather than intuitive; in the visual/verbal category and in the sequential/global categories the majority of the participants were visual and sequential respectively. This finding corroborates those of Kolmos and Holgaard (2008) who determined the chemistry, bio and health technology students of Aalborg University to be more active sensate, visual and sequential as well.

Kolb grouped the mental processes by which perceived information can be converted, into two categories; active experimentation and reflective observation (Kolb, 1984). Active experimentation involves testing, analysing or experimenting on the information in the external world. Reflective observation deals more with introspectively manipulating and examining the information (Felder \& Silverman, 1988). Active learners are better at active experimentation than reflective observation (Felder \& Silverman, 1988). It is expected that chemistry students would be more active than reflective since by the nature of their study there are usually involved experimentation, testing and analyzing rather than introspection.

Carl Jung described sensing and intuition as two ways people perceive the world (Jung, 1989). Sensing can be described as observing and gathering data through the senses and intuitive involves the indirect perception by speculation, imagination and hunches. Sensate learners like facts, data and experimentation. They are patient with details, good at memorizing facts and careful but can be slow. Intuitive learners prefer principles and theories (Felder \& Silverman, 1988). They like innovations dislike repetition and welcome complications. They are good at grasping new concepts and are quick but usually careless. Again it is easy to see why chemistry students are expected to be sensate learners since the bulk of their work tends to involve experimentation and analysis. The calculations are fairly straight forward and repetitive, and most of the theory is based on facts. 
Visual learners classify sensory information better with the use of diagrams, pictures, flow charts etc. Verbal learners classify sensory information better with spoken or written explanations (Felder, 1995). It is expected that a higher percentage of chemistry students will be visual learners. Although chemistry does have its share of written explanations, there are many instances where the ability to understand visual demonstrations become necessary. Chemistry lecturers have been using power point presentations incorporating various helpful diagrams and demonstrations into their lectures. In addition they sometimes add short videos which also appeal to the visual learner. It is also expected that chemistry students would be more sequential than global since sequential learners tend to learn in logical, linear steps and most scientific methods (figure 2) are presented in logical, linear steps (Felder \& Soloman, 2000).

\subsection{Learning Style and Level of study}

The results presented in table 4 seek to answer the research question: Is there any significant difference in the learning style categories of undergraduate chemistry students based on their level of study?

Table 4: Comparison of learning style categories based on the level of the undergraduate chemistry students at the University of the West Indies, Cave Hill Campus.

\begin{tabular}{|c|c|c|c|c|c|c|c|}
\hline Variables & Level & $\mathrm{N}$ & Mean & Std.Deviation & Df & $t$ & $\mathbf{P}$ \\
\hline \multirow{2}{*}{$\begin{array}{c}\text { Active/ } \\
\text { Reflective }\end{array}$} & $1^{\text {st }}$ years & 36 & 1.42 & 0.500 & \multirow{2}{*}{56} & \multirow{2}{*}{0.741} & \multirow{2}{*}{0.462} \\
\hline & $3^{\text {rd }}$ years & 22 & 1.32 & 0.477 & & & \\
\hline \multirow{2}{*}{$\begin{array}{l}\text { Sensate/ } \\
\text { Intuitive }\end{array}$} & $1^{\text {st }}$ years & 36 & 1.28 & 0.454 & \multirow{2}{*}{56} & \multirow{2}{*}{0.677} & \multirow{2}{*}{0.501} \\
\hline & $3^{\text {rd }}$ years & 22 & 1.36 & 0.492 & & & \\
\hline \multirow{2}{*}{ Visual/ Verbal } & $1^{\text {st }}$ years & 36 & 1.19 & 0.401 & \multirow{2}{*}{37.135} & \multirow{2}{*}{1.698} & \multirow{2}{*}{0.078} \\
\hline & $3^{\text {rd }}$ years & 22 & 1.41 & 0.503 & & & \\
\hline \multirow{2}{*}{$\begin{array}{c}\text { Sequential/ } \\
\text { Global }\end{array}$} & $1^{\text {st }}$ years & 36 & 1.31 & 0.467 & \multirow{2}{*}{56} & \multirow{2}{*}{0.638} & \multirow{2}{*}{0.526} \\
\hline & $3^{\text {rd }}$ years & 22 & 1.23 & 0.429 & & & \\
\hline
\end{tabular}

The results (Table 4) show that there was no significant difference between the level of the chemistry students and the learning style categories. Both levels display the expected learning styles for science students; Active; Sensate; Visual; and Sequential as also seen by Kolmos \& Holgaard (2008) in their study. The first years were more sensate and visual whereas the third years were determined to be more active and sequential. In the first years there are students with a diverse of majors and minors taking the first year chemistry courses so that not all of them move into third year chemistry. It is also possible that the third year chemistry students' learning styles could be refined over time as they progress with their degree (Robotham, 1999). Another reason could be that the chemistry students in previous levels that were reflective and global learners switched majors from chemistry to for example, psychology.

\subsection{Learning Style and Age}

\subsubsection{Active/Reflective learning Style}

Table 5: A comparison of the Active/Reflective learning styles based on the age of the undergraduate chemistry students at the University of the West Indies, Cave Hill Campus.

\begin{tabular}{|c|c|c|c|}
\hline Ages & N & Mean & Std. Deviation \\
\hline $16-18$ & 15 & 1.40 & 0.507 \\
\hline $19-21$ & 31 & 1.42 & 0.502 \\
\hline $22-24$ & 7 & 1.43 & 0.535 \\
\hline $25+$ & 5 & 1.00 & 0.000 \\
\hline Total & 58 & 1.38 & 0.489 \\
\hline
\end{tabular}


Table 6: The effect of age on the Active/Reflective Learning Styles in the undergraduate chemistry students at the University of the West Indies, Cave Hill Campus.

\begin{tabular}{|c|c|c|c|c|c|}
\hline & $\begin{array}{c}\text { Sum of } \\
\text { squares }\end{array}$ & Df. & $\begin{array}{c}\text { Mean } \\
\text { squares }\end{array}$ & F & Sig. \\
\hline Between groups & 0.792 & 3 & 0.264 & \multirow{2}{*}{1.109} & \multirow{2}{*}{0.354} \\
\hline Within groups & 12.863 & 54 & 0.238 & & \\
\hline Total & 13.655 & 57 & & & \\
\hline
\end{tabular}

Table 6 shows that there was no significant difference between the Active/Reflective learning styles based on the age in the undergraduate chemistry students $[F=1.109, p=0.354]$ but according to table 5 , across the range of age groups most of the chemistry students were active learners.

\subsubsection{Sensate/Intuitive learning Style}

Table 7: A comparison of the Senate/Intuitive learning styles based on the age of the undergraduate chemistry students at the University of the West Indies, Cave Hill Campus.

\begin{tabular}{|c|c|c|c|}
\hline Ages & N & Mean & Std. Deviation \\
\hline $16-18$ & 15 & 1.40 & 0.507 \\
\hline $19-21$ & 31 & 1.19 & 0.402 \\
\hline $22-24$ & 7 & 1.57 & 0.535 \\
\hline $25+$ & 5 & 1.40 & 0.548 \\
\hline Total & 58 & 1.31 & 0.467 \\
\hline
\end{tabular}

Table 8: The effect of age on the Sensate/Intuitive Learning Styles in the undergraduate chemistry students at the University of the West Indies, Cave Hill Campus.

\begin{tabular}{|c|c|c|c|c|c|}
\hline & Sum of squares & Df. & Mean squares & F & Sig. \\
\hline Between groups & 1.061 & 3 & 0.354 & \multirow{3}{*}{1.682} & \multirow{2}{*}{0.182} \\
\hline Within groups & 11.353 & 54 & 0.210 & \\
\hline Total & 12.414 & 57 & & \\
\hline
\end{tabular}

Table 8 also shows that there was no significant difference between the Sensate/Intuitive learning styles based on their age in the undergraduate chemistry students $[F=1.682, p=0.182]$ however, unlike all of the other age groups, those between 22-24 years of age are more intuitive than sensate (Table 7).

\subsubsection{Visual/Verbal learning style}

Table 9: A comparison of the Visual/Verbal learning styles based on the age of the undergraduate chemistry students at the University of the West Indies, Cave Hill Campus.

\begin{tabular}{|c|c|c|c|}
\hline Ages & N & Mean & Std. Deviation \\
\hline $16-18$ & 15 & 1.40 & 0.507 \\
\hline $19-21$ & 31 & 1.13 & 0.341 \\
\hline $22-24$ & 7 & 1.29 & 0.488 \\
\hline $25+$ & 5 & 1.80 & 0.447 \\
\hline Total & 58 & 1.28 & 0.451 \\
\hline
\end{tabular}


Table 10: The effect of age on the Visual/Verbal Learning Styles in the undergraduate chemistry students at the University of the West Indies, Cave Hill Campus.

\begin{tabular}{|c|c|c|c|c|c|}
\hline & Sum of squares & Df. & Mean squares & F & Sig. \\
\hline Between groups & 2.274 & 3 & 0.758 & 4.395 & 0.008 \\
\hline Within groups & 9.312 & 54 & 0.172 & & \\
\hline Total & 11.586 & 57 & & & \\
\hline
\end{tabular}

Table 10 shows that there was a significant difference between the Visual/Verbal learning styles based on the age of the undergraduate chemistry students [ $\mathrm{F}=4.395, \mathrm{p}=0.008$ ), however, all except the 25 and older age group were mainly visual rather than verbal learners (Table 9).

\subsubsection{Sequential/Global learning Style}

Table 11: A comparison of the Sequential/Global learning styles based on the age of the undergraduate chemistry students at the University of the West Indies, CaveHill Campus.

\begin{tabular}{|c|c|c|c|}
\hline Ages & N & Mean & Std. Deviation \\
\hline $16-18$ & 15 & 1.33 & 0.488 \\
\hline $19-21$ & 31 & 1.23 & 0.425 \\
\hline $22-24$ & 7 & 1.29 & 0.488 \\
\hline $25+$ & 5 & 1.40 & 0.548 \\
\hline Total & 58 & 1.28 & 0.451 \\
\hline
\end{tabular}

Table 12: The effect of age on the Sequential/Global Learning Styles in the undergraduate chemistry students at the University of the West Indies, Cave Hill Campus.

\begin{tabular}{|c|c|c|c|c|c|}
\hline & Sum of squares & Df. & Mean squares & F & Sig. \\
\hline Between groups & 0.205 & 3 & 0.068 & & \\
\cline { 1 - 4 } Within groups & 11.381 & 54 & 0.211 & \multirow{2}{*}{0.324} & \multirow{2}{*}{0.808} \\
\hline Total & 11.586 & 57 & & & \\
\hline
\end{tabular}

According to table 11, across all of the age groups the undergraduate chemistry students were mainly sequential learners rather than global learners however; there was no significant difference between the Sequential/Global learning styles based on the age group of the undergraduate chemistry students [F=0.324, $p=0.808]$ (Table 12).

\subsection{Academic Achievement \& Learning Style}

The academic achievement for this study was assessed by test on group theory as well as non-group theory chemistry. The non-group theory chemistry refers to topics such as atomic structure and kinetics for example. The group theory chemistry involves the analysis of molecular models in terms of symmetry elements and operations (Meyer \& Sargent, 2007; Harle \& Towns, 2010) and is based primarily on the application of aspects of mathematics to chemistry (Harle \& Towns 2010). It is thought that students may employ a different approach to learning when faced with group theory versus non-group theory chemistry. Both areas are taught by the same lecturer to the group of students who participated in the study and hence the variability due to change in lecturer have been minimized. Table 13 illustrates the significance of academic achievement based on the categories of the participants learning style. 
Table 13: Comparison of Achievement based on the Learning styles of the undergraduate chemistry students at the University of the West Indies, Cave Hill Campus.

\begin{tabular}{|c|c|c|c|c|c|c|c|}
\hline Achievement Test & Learning Styles & $\mathbf{N}$ & Mean & Std. Deviation & Df. & $t$ & $\mathbf{P}$ \\
\hline \multirow{8}{*}{$\begin{array}{l}\text { Non Group } \\
\text { Theory }\end{array}$} & Active & 36 & 77.00 & 16.227 & \multirow{2}{*}{56} & \multirow{2}{*}{1.416} & \multirow{2}{*}{0.162} \\
\hline & Reflective & 22 & 70.46 & 17.830 & & & \\
\hline & Sensate & 40 & 74.50 & 16.473 & \multirow{2}{*}{56} & \multirow{2}{*}{0.011} & \multirow{2}{*}{0.991} \\
\hline & Intuitive & 18 & 74.56 & 19.324 & & & \\
\hline & Visual & 42 & 74.99 & 16.856 & \multirow{2}{*}{56} & \multirow{2}{*}{0.334} & \multirow{2}{*}{0.739} \\
\hline & Verbal & 16 & 73.28 & 18.706 & & & \\
\hline & Sequential & 42 & 75.94 & 16.959 & \multirow{2}{*}{56} & \multirow{2}{*}{1.019} & \multirow{2}{*}{0.312} \\
\hline & Global & 16 & 70.78 & 17.947 & & & \\
\hline \multirow{8}{*}{ Group Theory } & Active & 36 & 55.03 & 20.098 & \multirow{2}{*}{56} & \multirow{2}{*}{0.657} & \multirow{2}{*}{0.514} \\
\hline & Reflective & 22 & 51.32 & 22.044 & & & \\
\hline & Sensate & 40 & 53.83 & 22.108 & \multirow{2}{*}{56} & \multirow{2}{*}{0.111} & \multirow{2}{*}{0.912} \\
\hline & Intuitive & 18 & 53.17 & 17.926 & & & \\
\hline & Visual & 42 & 56.29 & 17.833 & \multirow{2}{*}{56} & \multirow{2}{*}{1.607} & \multirow{2}{*}{0.114} \\
\hline & Verbal & 16 & 46.63 & 26.344 & & & \\
\hline & Sequential & 42 & 50.55 & 20.352 & \multirow{2}{*}{56} & \multirow{2}{*}{1.867} & \multirow{2}{*}{0.067} \\
\hline & Global & 16 & 61.69 & 20.182 & & & \\
\hline
\end{tabular}

Table 13 shows that there was no significant difference between the achievement scores and any of the categories of learning styles of the undergraduate chemistry students at the University of the West Indies, Cave Hill Campus. The results suggest that the learning styles; Active (Mean $=77.00$ ); Intuitive (Mean $=74.56$ ); Visual (Mean $=74.99$ ) and; Sequential (Mean $=75.94$ ) have better achievement scores in the non-group theory test whereas for the group theory test, the learning styles; Active (Mean $=55.03)$; Sensate (Mean $=53.83$ ); Visual (Mean $=56.29$ ) and; Global $($ Mean $=61.69$ ) had better achievement scores. Overall the students received higher scores in the non-group theory tests than the group theory tests.

It was expected that the learning styles associated with science students; Active; Sensate; Visual; Sequential; would have higher achievement scores in chemistry. This is because of how the inorganic chemistry course is taught at Cave Hill. The lecture utilizes power point presentations and schematics, which may appeal to visual and sequential learners more than verbal and global learners (Graf, et al., 2006; Graf, et al., 2007); and have small group tutorial sessions with active learning exercises, which may appeal more to the active learners (Graf, et. al., 2007). In addition sensate learners usually pay more attention to detail and therefore be better at recalling information as well as applying them to real life experiences.

In the non-group theory test however, the intuitive learners achieved higher scores than the sensate learners. This was a bit surprising since sensate learners, as previously mentioned, tend to pay more attention to details. However, topics such as atomic structure involve new theories and concepts to be learnt which may be more appealing to the intuitive learner.

In the group theory test, the global learners achieved higher score on average than sequential learners. Global learners assimilate information by first 'seeing the big picture', in this case seeing the whole molecules, then they go back to discover the details, in this case symmetry operations and point groups. This can be advantageous in group theory chemistry.

In addition, the lecturer teaches group theory with the students in small groups where model kits are utilized to build the models and with these models determine the symmetry operations and point groups of the molecules. With this topic active learners can benefit from this teaching style since they prefer to discuss and work in groups. This topic and test is especially advantageous to the visual learners and may explain the $17.2 \%$ difference between the visual and verbal achievement scores for the group theory tests as compared to the difference of $2.3 \%$ between the visual and verbal achievement scores for the non-group theory test. The visual learners, learners who are able to recall information better if administered to them visually, are able to take the models and work with them as opposed to the verbal learners who would rather make descriptions in writing. 


\subsection{Combined Effect and Relative Contribution of the Learning styles on Academic Achievement}

Tables 14 and 15 seek to answer research questions 4 and 5 which deals with the combined effect and contribution of the learning styles on academic achievement.

Table 14: Combined effect of learning style categories on academic achievement.

\begin{tabular}{|c|c|c|c|c|c|c|}
\hline \multirow{6}{*}{$\begin{array}{l}\text { Non-Group } \\
\text { Theory }\end{array}$} & \multicolumn{6}{|c|}{$\begin{array}{l}\text { R: } 0.230 \\
\text { R}^{2}: 0.053 \\
\text { Adjusted R2:-0.019 } \\
\text { Standard error:17.395 }\end{array}$} \\
\hline & \multicolumn{6}{|l|}{ ANOVA } \\
\hline & Model & Sum of Squares & Df & Mean square & $\mathrm{F}$ & Sig. \\
\hline & Regression & 895.031 & 4 & 223.758 & 0.739 & 0.569 \\
\hline & Residual & 16036.951 & 53 & 302.584 & & \\
\hline & Total & 16931.983 & 57 & & & \\
\hline \multirow{6}{*}{ Group Theory } & \multicolumn{6}{|c|}{$\begin{array}{l}\text { R: } 0.309 \\
R^{2}: 0.096 \\
\text { Adjusted R2: } 0.027 \\
\text { Standard error: } 20.458\end{array}$} \\
\hline & \multicolumn{6}{|c|}{ ANOVA } \\
\hline & Model & Sum of Squares & Df & Mean square & $\mathrm{F}$ & Sig. \\
\hline & Regression & 2347.414 & 4 & 586.853 & 1.402 & 0.246 \\
\hline & Residual & 22182.241 & 53 & 418.533 & & \\
\hline & Total & 24529.655 & 57 & & & \\
\hline
\end{tabular}

Table 15: Relative contribution of learning styles on the level of academic achievement

\begin{tabular}{|c|c|c|c|c|c|c|}
\hline \multirow{7}{*}{$\begin{array}{l}\text { Non- } \\
\text { Group } \\
\text { Theory }\end{array}$} & \multirow[t]{2}{*}{ Model } & \multicolumn{2}{|c|}{ Unstandardized coefficients } & & \multirow[t]{2}{*}{$\mathbf{F}$} & \multirow[t]{2}{*}{ Sig. } \\
\hline & & B & Std.Error & $\begin{array}{l}\text { coefficients } \\
\text { Beta }\end{array}$ & & \\
\hline & Constant & 92.889 & 13.594 & & 6.833 & 0.000 \\
\hline & Active/Reflective & -6.097 & 4.795 & -0.173 & -1.272 & 0.209 \\
\hline & Sensate/Intuitive & -.410 & 5.014 & -0.011 & -0.082 & 0.935 \\
\hline & Visual/Verbal & -2.280 & 5.250 & -0.060 & -0.434 & 0.666 \\
\hline & Sequential/Global & -5.108 & 5.275 & -0.134 & -0.968 & 0.337 \\
\hline \multirow{7}{*}{$\begin{array}{l}\text { Group } \\
\text { Theory }\end{array}$} & \multirow[t]{2}{*}{ Model } & \multicolumn{2}{|c|}{ Unstandardized coefficients } & $\begin{array}{l}\text { Standardized } \\
\text { coefficients }\end{array}$ & \multirow[t]{2}{*}{$\mathbf{F}$} & \multirow[t]{2}{*}{ Sig. } \\
\hline & & B & Std.Error & Beta & & \\
\hline & Constant & 58.377 & 15.988 & & 3.651 & 0.001 \\
\hline & Active/Reflective & -4.193 & 5.639 & -0.099 & -0.744 & 0.460 \\
\hline & Sensate/Intuitive & -2.103 & 5.897 & -0.047 & -.0357 & 0.723 \\
\hline & Visual/Verbal & -7.200 & 6.175 & -0.156 & -1.166 & 0.249 \\
\hline & Sequential/Global & 10.165 & 6.204 & 0.221 & 1.638 & 0.107 \\
\hline
\end{tabular}

The combination of the four learning style categories accounted for $5.3 \%$ of the variance $\left(R^{2}: 0.053 ; P: 0.569\right)$ in the nongroup theory test and $9.6 \%$ of the variance ( $\left.R^{2}: 0.096 ; P: 0.246\right)$ in the group theory test. While Table 14 suggests that statistically the four learning style categories combined do not contribute significantly to the achievement of the undergraduate chemistry students in either group theory or non-group theory chemistry at the University of the West Indies Cave Hill Campus, Table 15 suggests that the highest contributing learning style category to the achievement in non-group theory chemistry was the active/reflective category $(\beta=-0.173)$ and to the achievement in group theory chemistry the highest contributor was the sequential/global category. The contribution of the other learning style categories to the achievement in non-group theory chemistry in descending order was sequential /global $(\beta=-0.134)$, 
visual/verbal $(\beta=-0.060)$ and sensate/intuitive $(\beta=-0.011)$. Towards achievement in group theory chemistry, the contribution of the other learning style categories, also in descending order were visual/verbal $(\beta=-0.156)$, active Ireflective $(\beta=-0.099)$ and sensate/intuitive $(\beta=-0.047)$.

\section{Conclusion}

The prevailing learning styles, according to the index of learning styles, in undergraduate chemistry students at the University of the West Indies, Cave Hill Campus were found to be Active, Sensate, Visual and Sequential. The study showed that there was no significant difference between achievement scores in either group theory or non-group theory chemistry based on the learning styles of the undergraduate chemistry students at the University of the West Indies Cave Hill Campus. Furthermore, the combined learning styles negligibly predict the students' achievement in the chemistry assessed and not statistically significantly so.

\section{References}

Abidin, M. J. Z., Rezaee, A. A., Abdullah, H. N., \& Singh, K. K. B. (2011) Learning Styles and Overall Academic Achievement in a Specific Educational System. International Journal of Humanities and Social Science, 1(10), 143-152.

B., O. J. T., \& Wale, O. J. (2012). Study habits and academic achievement in core subjects among junior secondary school students in Ondo State, Nigeria. Bulgarian Journal of Science and Education Policy (BJSEP), 6(1), 155-170.

Bajraktarevic, N., Hall, W., \& Fullick, P. (2003). Incorporating learning styles in hypermedia environment: Empirical evaluation. 41-52. Retrieved from http://wwwis. win.tue.nl/ah2003/proceedings/paper4.pdf

Bonham, B. S., \& Boylan, H. R. (1993). A new look at learning styles. Research in Developmental Education, 10 (4).

Cassidy, S. (2004). Learning Styles: An overview of theories, models and measures. Educational Psychology, 24, 419-446. Retrieved from http://www.acdowd-designs.com/sfsu_860_11/LS_OverView.pdf

Center for Instruction, R. a. T. (2012). Models of Learning Styles. Learning Styles Site Retrieved 12th November, 2012.

Chapelle, C. (1995). Field-Dependence/Field-Independence in the Second Language Classroom. Boston: Heinle and Heinle Publishers

Coffield, F., Moseley, D., Hall, E., \& Ecclestone, K. (2004). Learning styles and pedagogy n post-16 learning: A systematic and critical review. London: LSRC reference.

Cuthbert, P. F. (2005). The student learning process: Learning styles or learning approaches? Teaching in Higher Education, 10(2), 235249.

Damavandi, A. J., Mahyuddin, R., Elias, H., Daud, S., \& Shabani, J. (2011). Academic Achievement of Students with Different Learning Styles. International Journal of Psychological Studies, 3(2), 186-192. http://dx.doi.org/10.5539/ijps.v3n2p186

Dunn, R. S., \& Dunn, K. J. (1993). Teaching secondary students through their individual learning styles. Boston: Allyn and Bacon.

Dunn, R. S., \& Griggs, S. A. (1998). Learning styles and the nursing profession: National League for Nursing Press.

Felder, R. M. (1995). A longitudinal study of engineering student performance and retention. IV. Instructional methods and student responses to them. Journal of Engineering Education, 84(4), 361-367.

Felder, R. M. (1996). Matters of Style. ASEE Prism, 6, 18-23. Retrieved from http://www4.ncsu.edu/ unity/lockers/users/f/felder/public/ Papers/LS-Prism.htm

Felder, R. M., \& Brent, R. (2005). Understanding student differences. Journal of Engineering Education, 94(1), 57-72.

Felder, R. M., Felder, G. N., \& Dietz, E. J. (1998). A longitudinal study of engineering student performance and retention. V. Comparisons with traditionally-taught students (Vol. 87, pp. 469-480): American society for engineering education.

Felder, R. M., \& Henriques, E. R. (1995). Learning and teaching styles in foreign and second language education. Foreign Language Annals, 28(1), 21-31.

Felder, R. M., \& Silverman, L. K. (1988). Learning and Teaching Styles in Engineering Education. Engineering Education, 78(7), 674681.

Felder, R. M., \& Silverman, L. K. (1988). Learning and teaching styles in engineering education (Vol. 78, pp. 674-681).

Felder, R. M., \& Soloman, B. A. (2000). Learning styles and strategies. [Online] Available: http://www2.ncsu.edu/unity/lockers/users If/felder/public/lLSdir/styles.htm (November 12, 2012)

Felder, R. M., \& Spurlin, J. (2005). Applications, Reliability and Validity of the Index of Learning Styles. International Journal on Engineering Education, 21(1), 103-112. Retrieved from http://www4.ncsu.edu/unity/lockers/users//ffelder/public/lLSdir/lLS Validation\%28IJEE\%29.pdf

Garner-O'Neale, L. D., \& Harrison, S. (2013). An Investigation of the Learning styles and Study Habits of Chemistry Undergraduates in Barbados and their Effect as Predictors of Academic Achievement in Chemical Group Theory. Journal of Educational and Social Research, 3(2), 107-122.

Gordon, D., \& Bull, G. (2004). The Nexus Explored: A Generalised Model of Learning Styles. 4, 1-8. [Online] Available : http://www.comp.dit.ie/dgordon/publications/author/siite2004/nexuspaperv4.pdf 
Graf, S., Viola, S. R., \& Kinshuk, T. L. (2006). Representative characteristics of Felder-Silverman learning styles: An empirical model. Paper presented at the Proceedings of the IADIS International Conference on Cognition and Exploratory Learning in Digital Age (CELDA 2006), Barcelona, Spain.

Graf, S., Viola, S. R., Leo, T., \& Kinshuk. (2007). In-Depth Analysis of the Felder-Silverman Learning Style Dimensions. Journal of Research on Technology in Education,, 40(1), 1-5.

Graham, J. C., Garton, B. L., \& Gowdy, M. (2001). The Relationship Between Student's Learning Styles, Instructional Performance, and Student Learning in a Plant Propagation Course. NACTA JOURNAL, 45(4), 30-35.

Griggs, S. A. (1991). Learning Styles Counseling., 1-3. [Online] Available: http://www.google.com/url?sa=t\&rct=i\&q=\&esrc=s\&source =web\&cd=1\&ved=0CCAQFjAA\&url=http\%3A\%2F\%2Fcfcc.edu\%2FSACS\%2FQEP\%2FLearningstylescounselingGriggs1991.rtt\& ei=7PGKUJqxHIqY9QTSu4GoDg\&usg=AFQjCNHdjUDIT2el69qkFgN-TIhSW4YS_w\&sig2=ADy_B5fAegRr_2iZMD0raw

Harle, M., \& Towns, M. (2010). A Review of Spatial Ability Literature, Its Connection to Chemistry, and Implications for Instruction. Journal of Chemical Education, 88(3), 351-360. Retrieved from http://www.chem.purdue.edu/towns/ Towns\%20Publications/Harle\%20Towns\%202010.pdf

Havola, L., Silferberg, H., \& Joutsenlahti, J. (2011). New engineering students' learning styles and basic skills in mathematics: Käsikirjoitus.

Heineman, P.L. (1995) Grasha and Reichmann Student Learning Style Scales. [Online] Available: http://www.personalityproject.org/others/heineman/grslss.htm. (19, May, 2013).

Hickcox, L. K. (1995). Learning styles: A survey of adult learning style inventory models. The importance of learning styles: Understanding the implications for learning, course design, and education, 25-47.

Jung, C. G. (1989). Psychological types (Vol. 4): Routledge.

Kagan, J., \& Kogan, N. (1970). Individual variation in cognitive processes (Vol. 1, pp. 1273-1365): Wiley New York.

Kanninen, E. (2008). LEARNING STYLES AND E-LEARNING. Master of Science. Retrieved from http://hlab.ee.tut.fi/video/bme/evicab/astore/delivera/wp4style.pdf.

Keefe, J. W. (1979). Learning style: An overview. In NASSP's Student learning styles:Diagnosing and prescribing programs. Reston, VA: National Association of Secondary School Principals, 1-17.

Kolb, D. (1984). Experiential learning: experience as the source of learning and development Retrieved from http://academic.regis.edu/ed205/Kolb.pdf.

Kolmos, A., \& Holgaard, J. E. (2008). Learning styles of science and engineering students in problem and project based education.

Matthews, D. B. (1991). The effects of learning style on grades of first-year college students (Vol. 32, pp. 253-268): Springer.

Meyer, D. E., \& Sargent, A. L. (2007). An interactive computer program to help students learn molecular symmetry elements and operations. Journal of Chemical Education, 84(9), 1551. Retrieved from http://www.ecu.edu/cscas/chem/upload/Documentation web.pdf.

Montgomery, S. M., \& Groat, L. N. (1998). Student Learning Styles And Their Implications For Teaching (Vol. 10, pp. 1-8): The Center For Research On Learning And Teaching.

Nunnally, J. C., Bernstein, I. H., \& Berge, J. M. F. (1967). Psychometric theory (Vol. 2): McGraw-Hill New York.

Pittenger, D. J. (1993). Measuring the MBTI...And Coming Up Short. Journal of Career Planning and Placement,.

Ritchie, L. (2006). Constructing College Couirse to Facilitate, Assess, and Document Learning. Blue Print for Learning, 310. Retrieved from https://docs.google.com/viewer?a=v\&q=cache:z6VeN HT70oJ:centeach.uiowa.edu/materials/Grasha\%2520Reichmann \%2520 student\%2520Learning\%2520Style\%2520Scales\%2520Inventory.pdf+\&hl=en\&pid=bl\&srcid=ADGEESgJkjXvXWFZjtQg MCsMCs9EQkSkHqsXs2a1v6uOEztQPw_ZOP6uhfbW8ksMt8JKA3xnO6rkfTOL7CwMfBCEOr7c9911jiNI8h8nV8GOjEPAaf0KXR xvR3OrywiCBGLh7TT9u7oX\&sig=AHIEtbQ23WomLpayACyeC-ot2EaS9IPdFw

Robotham, D. D. (1999). The application of learning style theory in higher education teaching. [Online] Available: http://www2.glos.ac.uk/gdn/discuss/kolb2.htm (12 November, 2012)

Sidek, H. J., Noor, S. M., \& Jusoff. K. (2009) The Social Interaction Learning Styles of Science and Social Science Students. Asian Social Science, 5(7), 58-64.

Smith, P., \& Dalton, J. (2005). Getting to Grips with Learning Styles. 4-6. Retrieved from http://www.google.com/url?sa=t\&rct=i\&q=\&esrc=s\&source=web\&cd1\&ved=0CCAOFiAA\&url=http\%3A\%2F\%2Fwww.ncver.e du.au\%2Fpopups\%2Flimit download.php\%3Ffile\%3Dresearch\%2Fproj\%2Fnd3103b.pdf\&ei=pyKUOKiGIrM9ASPy4GYBg\&usg=AFOjCNGmibooYxynxp4L46eq13a3vCxiow\&sig2=70pBsfKfxH1CtRCb2bMbmQ

Stewart, K. L., \& Felicetti, L. A. (1992). Learning styles of marketing majors. Educational Research Quarterly,, 15(2), 15-23.

SUNY Cortland, (n.d.) Student Learning Styles Scales - Grasha-Reichmann Retrieved 12th November, 2012, 2012, from http://web.cortland.edu/andersmd/learning/Grasha.htm

Tavakol, M., \& Dennick, R. (2011). Making sense of Cronbach's alpha. International Journal of Medical Education, 2, 53-55.

Vainionpää, J. (2006). Erilaiset oppijat ja oppimateriaalit verkko-opiskelussa: Tampere University Press.

Vawda, A. (2005). The Learning Styles of First Year University Students (Magister Artium dissertation, Nelson Mandela Metropolitan University, South Africa) Retrieved from http://nmmu.ac.za/documents/theses/avawda.pdf .

Zywno, M. S., \& Waalen, J. K. (2002). The effect of individual learning styles on student outcomes in technology-enabled education. Global J. of Engng. Educ., Australia, 6(1) 